\title{
The Influence of Different Antifoaming Agent on Concrete
}

\author{
Juxiang Xing, Yao Bi, Xing Li \& Long Xiong \\ Department of Technology Center, China State Construction Ready Mixed Concrete CO., LTD, Wuhan, \\ 430074, China
}

\begin{abstract}
This paper mainly study of four different kinds of antifoaming agent, which can make different influence on the concrete performance and durability. The experimental results show that: According to the comprehensive performance of concrete, the fluidity of concrete with the addition of the polyether modified silicone antifoaming agent is the best, the fresh concrete slump, expansion and the density fluctuates less than another type's antifoaming agent. Concrete slump loss is also less than another type's antifoaming agent. The comprehensive performance of the concrete added with polyether is also excellent. The silicone oil emulsion type antifoaming agent has a faster bubbles breaking speed, while big fluctuates on the fluidity of concrete when dosage changes.
\end{abstract}

KEYWORD: Antifoaming agent; Mineral oil; Emulsified silicone oil; Polyether; Polyether modified silicone

\section{INTRODUCTION}

Concrete is one kind of multiphase materials, which is composed of solid, liquid, gas phase, so the existence of bubbles is inevitable and unavoidable. when the air content of concrete is more than $4 \%$, especially many big bubbles $(\mathrm{d}>100 \mathrm{~nm}$ ) (Caneouet $\mathrm{R}$ et al, 2000), The quality of the project will have some big risk, because big bubbles can assembly reduce concrete cross section size, the strength of the concrete will be reduced either (Denkov N D, 2004) (Lamontagne A, 1996). Many research showed that when the air content of concrete increases $1 \%$, the concrete compressive strength decreases 5\% (Older I, 1985) (X. Ouyang et al, 2008). Each 1\% increase of the air content, the compressive strength decreases $4-6 \%$ (Zeng J L, 2007). In low strength concrete, the $3-6 \%$ air content has no influence on strength, When the air content is more than $6 \%$, the compressive strength will be inevitably affected (Zhang $\mathrm{J} \mathrm{X}$ et al, 2008), the bubbles reduced the effective thickness of the reinforced layer, accelerated the process of carbonization of concrete surface, which affects its corrosion resistance, big air bubbles will cause the honeycomb pitting surface at the same time.

The bubbles' size, number and distribution has significant effect on the workability, strength and durability of concrete. In practical engineering application, we always add antifoaming agent to eliminate harmful bubbles; there are many different kinds of antifoaming agent, this paper mainly study of four different kinds of antifoaming agent and their influence on concrete.

\section{EXPERIMENTAL SECTIONS}

\subsection{Raw materials}

The cement used is P.O 42.5 with specific area of $350 \mathrm{~m}^{2} / \mathrm{kg}$ from Huaxin cement factory in china; Fly ash is from Macheng fly ash I (D50 $12 \mathrm{~m}$ ); Slag is from China Construction Ready Mixed Concrete Co. Ltd. S95 powder, river quartz sand with the fineness modulus of 2.57 and crushed aggregate with the size of $5 \pm 25 \mathrm{~mm}$ were used. The Physical properties of cement and mineral admixture is shown in Table 1.

Table 1 Physical properties of cement and mineral admixture

\begin{tabular}{lllll}
\hline $\begin{array}{l}\text { raw ma- } \\
\text { terial }\end{array}$ & $\begin{array}{l}\text { density } \\
/ \mathrm{g} \cdot \mathrm{cm}^{-3}\end{array}$ & $\begin{array}{l}\text { specific sur- } \\
\text { face area } \\
/ \mathrm{m}^{2} \cdot \mathrm{kg}^{-1}\end{array}$ & $\begin{array}{l}\text { Water } \\
\text { demand } \\
\text { ratio } / \%\end{array}$ & $\begin{array}{l}\text { Mobility } \\
\text { ratio } / \%\end{array}$ \\
cement & 3.20 & 350 & 100 & 100 \\
fly ash(I) & 2.73 & 950 & 110 & 105 \\
slag & 2.80 & 455 & 105 & 100 \\
\hline raw ma- & $\mathrm{R} 28 / \mathrm{MPa}$ & $\begin{array}{l}\text { 28d ratio of compressive } \\
\text { strength/\% }\end{array}$ & \\
terial & & 100.0 & \\
cement & 61.5 & 81.8 & & \\
fly ash(I) & 50.3 & 98.1 & & \\
slag & 51.0 & 9 &
\end{tabular}

The antifoaming agent in our experiment including mineral oil from Guangzhou bo cheung chemical 
technology co., LTD. The polyether is from Hubei new universal chemical co., LTD. The emulsified silicone oil is from Yingchuang Degussa (china) Investment Co., Ltd. Shanghai Branch. Polyether modified silicone is from BASF. polycarboxylate superplasticizers (10\% solid content) is from China Construction Ready Mixed Concrete Co. Ltd.

\subsection{Characterization and evaluation of samples}

The air content of fresh concrete are determined by LC-615A (Sanyo, Japan) according to the Chinese Construction Materials Standard JC/T601-1995.

The tests of the fluidity and the compressive strength of the concrete are conducted according to the Chinese National Standard GB/T 50080-2002, GB/T 50081-2002 and GB/T 50082-2009.

\section{RESULTS AND DISCUSSION}

\subsection{The basic performance indexes of the antifoaming agent}

The basic performance indexes of the antifoaming agent is shown in Table 2, including the $\mathrm{PH}$; the content of active matter and the compatibility with polycarboxylate superplasticizers. The compatibility of silicone oil emulsion and polycarboxylate superplasticizers is poor, there is mild floating oil when mineral oil emulsion antifoaming agent added to the polycarboxylate superplasticizers. The others scattered well.

\subsection{Effect of different anti foaming agent on the properties of fresh concrete}

In this paper, the strength grade of concrete test is C35, concrete mix proportion is shown in table 3, we used $102 \mathrm{~g}$ polycarboxylate superplasticizers $(10 \%$ solid content) as the additive after a lot of experiments, the fresh concrete slump and expansion, the density and compressive strength data of concrete is shown in table 4.

Table 3 concrete mix proportion

\begin{tabular}{lllllll}
\hline $\begin{array}{l}\text { Mixing } \\
\text { proportion }\end{array}$ & water & cement & $\begin{array}{l}\text { fly } \\
\text { ash }\end{array}$ & slag & sand & $\begin{array}{l}\text { crushed } \\
\text { stone }\end{array}$ \\
\hline$\left(\mathrm{kg} / \mathrm{m}^{3}\right)$ & 152 & 210 & 90 & 80 & 810 & 1060 \\
\hline
\end{tabular}

Table4 The workability and compressive strength of concrete

\begin{tabular}{|c|c|c|c|c|c|c|}
\hline \multirow{2}{*}{ Serial } & \multirow{2}{*}{\multicolumn{2}{|c|}{ Type }} & \multirow{2}{*}{ Dosage(g) } & \multicolumn{3}{|c|}{ Concrete slump / expansion(mm) } \\
\hline & & & & $0 \mathrm{~min}$ & & \\
\hline \multirow[b]{2}{*}{1} & \multirow{2}{*}{\multicolumn{2}{|c|}{ mineral oil }} & 0.05 & $200 / 540$ & \multicolumn{2}{|c|}{$190 / 500$} \\
\hline & & & 0.1 & $220 / 560$ & \multicolumn{2}{|c|}{$200 / 500$} \\
\hline \multirow{2}{*}{2} & \multirow{2}{*}{\multicolumn{2}{|c|}{ polyether }} & 0.05 & $220 / 560$ & \multicolumn{2}{|c|}{$190 / 530$} \\
\hline & & & 0.1 & $225 / 560$ & \multicolumn{2}{|c|}{$200 / 535$} \\
\hline \multirow{2}{*}{3} & \multirow{2}{*}{\multicolumn{2}{|c|}{ emulsified silicone oil }} & 0.05 & $210 / 550$ & \multicolumn{2}{|c|}{$180 / 490$} \\
\hline & & & 0.1 & $200 / 530$ & \multicolumn{2}{|c|}{$180 / 475$} \\
\hline \multirow{2}{*}{4} & \multirow{2}{*}{\multicolumn{2}{|c|}{ Polyether modified silicone }} & 0.05 & $225 / 590$ & & \\
\hline & & & 0.1 & $230 / 595$ & & \\
\hline \multirow{2}{*}{ Serial } & \multirow{2}{*}{ Type } & \multirow{2}{*}{ Dosage(g) } & \multicolumn{2}{|c|}{ Density $\left(\mathrm{kg} / \mathrm{m}^{3}\right)$} & \multicolumn{2}{|c|}{ Compressi-ve strength (MPa) } \\
\hline & & & $0 \mathrm{~min}$ & $45 \min$ & $7 d$ & $28 \mathrm{~d}$ \\
\hline \multirow{2}{*}{1} & \multirow{2}{*}{ mineral oil } & 0.05 & 2350 & 2410 & 28.1 & 37.3 \\
\hline & & 0.1 & 2374 & 2415 & 28.7 & 36.8 \\
\hline \multirow{2}{*}{2} & \multirow{2}{*}{ Polyeth-er } & 0.05 & 2348 & 2370 & 27.6 & 38.1 \\
\hline & & 0.1 & 2354 & 2385 & 28.9 & 39.5 \\
\hline \multirow{2}{*}{3} & \multirow{2}{*}{ Emulsify-ied silicone oil } & 0.05 & 2357 & 2418 & 28.9 & 37.6 \\
\hline & & 0.1 & 2385 & 2437 & 29.4 & 38.8 \\
\hline \multirow{2}{*}{4} & \multirow{2}{*}{ Polyeth-er modifie-d silicone } & 0.05 & 2328 & 2346 & 30.0 & 39.6 \\
\hline & & 0.1 & 2334 & 2357 & 30.7 & 40.5 \\
\hline
\end{tabular}

According to the comprehensive performance of concrete, the fluidity of concrete with the addition of the polyether modified silicone antifoaming agent is the best, the fresh concrete slump, expansion and the density fluctuates less than another types antifoaming agent. Concrete slump loss is also less than another type's antifoaming agent. The comprehensive performance of the concrete added with polyether is 
also excellent. Because of polyether modified silicon's special surface tension, which is benefit to the stability of small bubbles in concrete, the fluidity of concrete slump and maintain ability is improved by these small bubbles ball bearing effect. The silicone oil emulsion type antifoaming agent has a faster bubbles breaking speed, while big fluctuates on the fluidity of concrete when dosage changes, concrete slump loss is the fastest one, it may be because the bubbles are not stable in the concrete.

\subsection{Hardened concrete apparent}

Surface bubbles affect the appearance quality of the concrete, also it also may affect the strength and the durability of the structure. Hardened concrete apparent with different antifoaming agents is shown in Table 5: there is no obvious harmful pore when using polyether modified silicone and polyether antifoaming agent, which may benefit enormously from its special surface tension; there are harmful holes when using emulsified oil antifoaming agent, the holes affect the appearance and durability of the project.

Table 5 Hardened concrete apparent

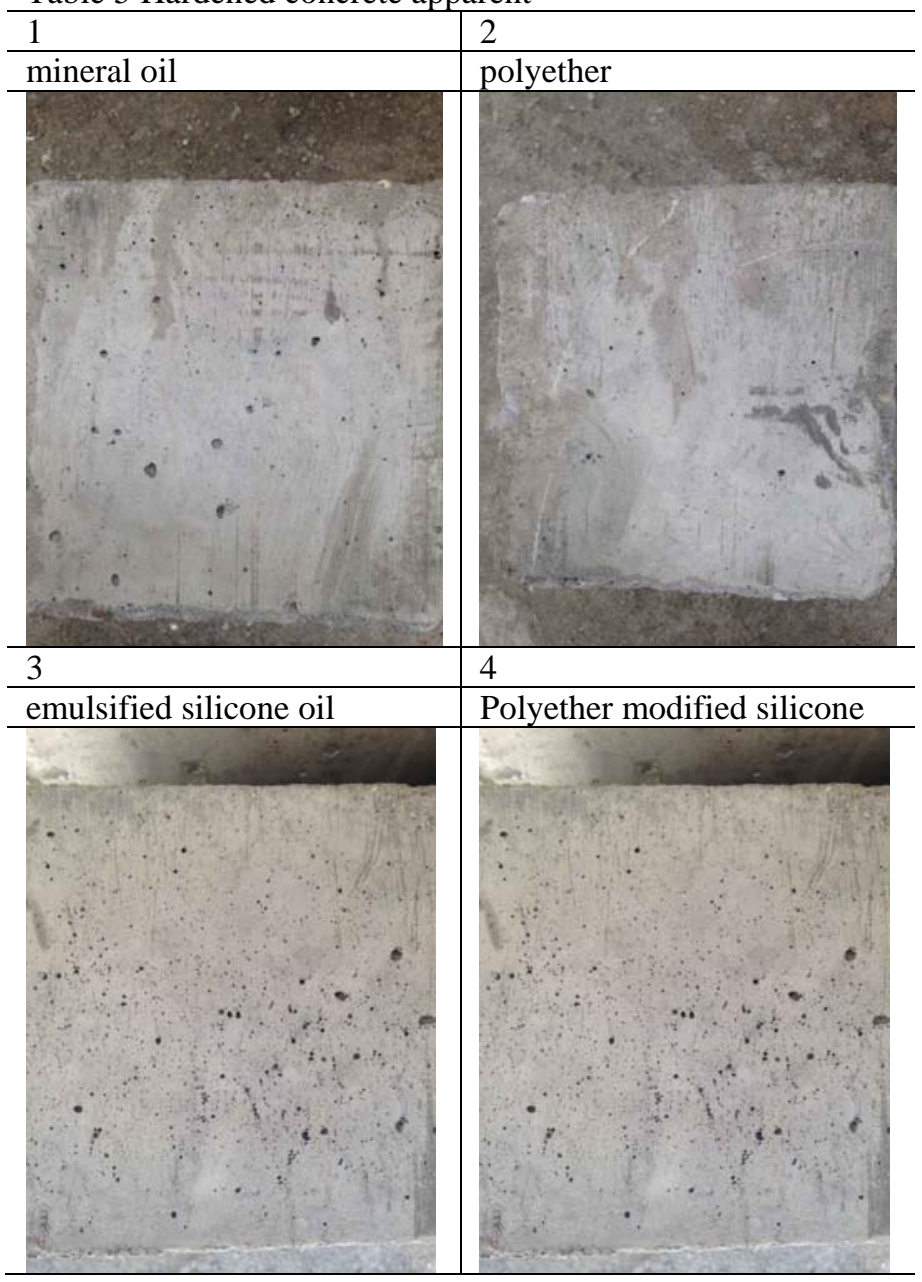

\section{CONCLUSIONS}

This paper compares four different chemical composition of antifoaming products, mineral oil 、 polyether vemulsified silicone oil and Polyether modified silicone respectively; The bubble breaking speed, restraining bubbles ability and bubbles stability are different when adding different types of defoaming agent. According to the comprehensive performance of concrete, the fluidity of concrete with the addition of the polyether modified silicone antifoaming agent is the best, the fresh concrete slump, expansion and the density fluctuates less than another types antifoaming agent. Concrete slump loss is also less than another types antifoaming agent, at the same time, hardened concrete apparent has no obvious harmful pore. The comprehensive performance of the concrete added with polyether is also excellent. Because of polyether modified silicon's special surface tension, which is benefit to the stability of small bubbles in concrete, the fluidity of concrete slump and maintain ability is improved by these small bubbles ball bearing effect. The silicone oil emulsion type antifoaming agent has a faster bubbles breaking speed, while big fluctuates on the fluidity of concrete when dosage changes, concrete slump loss is the fastest one, it may be because the bubbles are not stable in the concrete.

We need choose the suitable antifoaming products according to the engineering need; also we can mix two or more than two kinds of defoaming agent to improve the concrete comprehensive performance.

\section{REFERENCES}

Caneouet R. et al. Function Polysiloxanes. I. Micorsturcture of Polysiloxnaes by Cationie CoPolmyerization. [J]. Joumal of Polymer Science, Part A: Polymer Chemistry, 2000, 38(5):826.

Denkov N D. Mechanisms of foam destruction by oil-based antifoams[J].2004,26.20(22):9463-505.

Lamontagne A, Pigeon M, Pleau R, et al. Use of air-entraining admixtures in dry-mix shotcrete. ACI Mater J 1996; 93(1):69-74.

Older I. Investigations on the relationship between porosity, structure and strength of hydrated Portland cement pastes:II. Effects of pore structure and degree of hydration. Cem Concr Res1985; 15(4):401-10.

X. Ouyang et al. The feasibility of synthetic surfactant as an air entraining agent for the cement matrix. Construction and Building Materials 2008; 22:1774-1779.

Zeng J L. Matsuda-machi, Silicone antifoaming agent [P]. US 7294653.2007.

Zhang J X. et al. Study on the evaluation method of the appearance quality of concrete. [J].concrete, 2008(1): 95-98. 